\title{
ODKRYĆ PIĘKNO W STAROŚCI... . Kobieta W JeSIENi ŻYCIA W ŚWIETLE WybranyCh Źródee XIX I XX STUlecia
}

Materiałem badawczym, na którym oparte zostały obecne rozważania, była w pierwszej kolejności książka Klementyny z Tańskich Hoffmanowej ${ }^{1} O$ powinnościach kobiet. Autorka, pisząc na temat społecznych ról i obowiązków dziewiętnastowiecznych przedstawicielek słabej płci, dostrzegła potrzebę omówienia problemu starzenia się pań. Drugą publikacją, którą wzięto pod uwagę, była rozprawa Franciszka Olszewskiego Starość. Popularny wykład fizjologii, psychologii, medycyny i higieny względnie do wieku starego ${ }^{2}$, w której zagadnienie przedstawione zostało z perspektywy lekarza. W obecnej analizie zestawiono oba źródła. Wspomniano ponadto o wybra-

\footnotetext{
${ }^{*}$ Aldona Jankowska — słuchaczka Studium Doktoranckiego Języka, Literatury i Kultury Uniwersytetu Łódzkiego. Jej zainteresowania badawcze oscylują wokół literatury Młodej Polski (ze szczególnym uwzględnieniem pisarstwa kobiecego), obyczajowości i sztuki XIX wieku, a także zagadnień dotyczących tzw. „kwestii kobiecej” (emancypacja, feminizm, mizoginizm).

${ }^{1}$ Klementyna z Tańskich Hoffmanowa (1798-1845) — pisarka i pedagog, pomysłodawczyni i redaktorka pierwszego polskiego miesięcznika adresowanego do najmłodszych pod tytułem „Rozrywki dla dzieci” (Warszawa 1824-1828), autorka wielu cieszących się popularnością książek dla dzieci i młodzieży. Autorka wielu prac dydaktycznych. Zob. Oświecenie, [w:] Bibliografia Literatury Polskiej - Nowy Korbut, t. 6, cz. 1, Warszawa 1970, s. 318-331; I. Łossowska, Klementyna Hoffmanowa z Tańskich, [w:] Pisarze Polskiego Oświecenia, red. T. Kostkiewiczowa, t. 3, Warszawa 1996, s. 819-834; Tańska (Hoffmanowa) Klementyna, [w:] Dawni Pisarze Polscy od początków piśmiennictwa do Mtodej Polski. Przewodnik biograficzny i bibliograficzny, red. R. Loth, t. 4, Warszawa 2003, s. 234-237. J. Sowiński, O uczonych Polkach, Warszawa 1821 , s. 143-156.

${ }^{2}$ Dziewiętnastowieczna praca stanowi przekład francuskiego oryginału Traité de la Vieillesse autorstwa lekarza Josepha Henriego Reveillé-Parise’a (1782-1852). Książka składa się z czterech części. Pierwsza część - Fizjologia, czyli życie wedtug praw przyrodzenia w sposób ogólny definiuje starość i charakteryzuje czynności życiowe ludzkiego organizmu, część druga - Stosunki organiczno-psychiczne zawiera rozważania o pracy umysłu osób starszych, ich uczuciach i emocjach. W trzeciej części - Uwagi ogólne. Pierwsza przyczyna chorób w starości autor przedstawia charakterystykę chorób najczęściej spotykanych u seniorów oraz sformułował zasady postępowania z osobami cierpiącymi na typowe przypadłości wieku podeszłego. Czwarta, najbardziej rozbudowana część - Higiena. Życie pod jej opieka, poświęcona została między innymi sposobom radzenia sobie z postępującymi objawami starzenia się organizmu (postulat akceptacji nieuchronnych zmian psychofizycznych), roli odpowiedniego odżywiania i higienicznego trybu życia, zgubnym skutkom ulegania nałogom oraz prawdopodobnym przyczynom długowieczności. Powstanie monografii, jak zaznaczył Olszewski, wynikało z potrzeby wypełnienia luki w polskich badaniach na temat procesu starzenia się człowieka.
} 
nych artykułach z czasopisma „Bluszcz”3 — jednego z ważniejszych pism kobiecych XIX i początku XX wieku, które poruszało omawiany tu temat.

Warto zaznaczyć, że problematyka senilna często pojawiała się w poradnikach i artykułach prasowych adresowanych do kobiet. Już w pierwszej połowie XIX stulecia zaczęły się ukazywać drukiem teksty zawierające różnego rodzaju wskazówki dotyczące postępowania z osobami starszymi. Cieszyły się one dużą poczytnością. Dawały bowiem odpowiedzi na istotne społecznie pytania, podsuwały rozwiązania wielu problemów dnia codziennego, stanowiły skondensowany zbiór praktycznej wiedzy wypływającej z osobistych doświadczeń autorów. Tematyka poruszana na ich kartach była szeroka. Porady kierowane zarówno do kobiet, jak i mężczyzn, dotyczyły sposobów zachowania zdrowia oraz dobrego samopoczucia w jesieni życia. Mówiły o akceptacji zmian zachodzących z upływem lat w organizmie człowieka.

Wspomniana wcześniej pisarka i pedagog Klementyna z Tańskich Hoffmanowa udzielała swoim czytelniczkom wielu cennych porad, które mogły okazać się dla nich przydatne w podeszłym wieku. W książce $O$ powinnościach kobiet zwracała uwagę na konieczność otoczenia szacunkiem osób starszych. Podkreślała, że nie należy poddawać się negatywnym nastrojom z powodu szybko upływającego czasu oraz narastających trudności. W wypełnianiu codziennych zadań wszystkim seniorkom dotkniętym melancholią i zniechęceniem proponowała zmianę myślenia. Nie powinny one, jej zdaniem, zamartwiać się tym, co nie zależy od nich samych, ale skupić uwagę na sprawach, na które mają wpływ.

Pisarka zachęcała kobiety w starszym wieku do aktywności. Radziła, aby znalazły sobie cel, do którego będą zmierzały. Podpowiadała, że starość to nowy etap życia, który może przynieść wiele korzyści zarówno im samym, jak i młodszym członkom rodziny. Starość nie jest okresem, w którym należy całkowicie usunąć się w cień. Przeciwnie, seniorki powinny dzielić się z młodszym pokoleniem doświadczeniami i życiową mądrością. To sprawi, że będą czuły się potrzebne i ważne, a w rezultacie unikną depresji.

\footnotetext{
3 „Bluszcz” — to najdłużej ukazujące się czasopismo kobiece w Polsce, które wychodziło w Warszawie od 1865 do 1939 roku. Na rynku wydawniczym pismo o objętości od 8 do 24 stron ukazywało się jako tygodnik. Zdarzało się jednak, że z powodu strajku drukarzy pojawiało się rzadziej, najczęściej jako numer podwójny. W latach 1918-1939 „Bluszcz” zamieszczał różne dodatki: Mody i roboty (pod red. Marii Podhorskiej-Okołów); dodatek literacki obejmujący powieści w odcinkach, nowele, opowiadania i wiersze; Komunikat Biura Prasowego dla Spraw Kobiecych (pod red. Zofii Bogórskiej); Wzory na hafty; Kultura ciała (pod red. Julii Świtalskiej); Nasza mównica; Wychowanie i szkoła; Nasz lekarz; Turystyczny $i$ uzdrowiskowy. Kilkakrotnie zmieniał się tytuł czasopisma: „Pismo Tygodniowe Ilustrowane Poświecone Sprawom Kobiecym”, „Pismo Tygodniowe”, „Pismo Tygodniowe Ilustrowane dla Kobiet”, „SpołecznoLiteracki Ilustrowany Tygodnik Kobiecy”. Od 1939 roku periodyk nosił tytuł — „Tygodnik Kulturalnej Rodziny”. (Szerzej na temat czasopisma zob. J. Chwastyk-Kowalczyk, „Bluszcz” w latach 1918-1939, Kielce 2003). Redaktorem „Bluszczu” była w latach 1865-1918 Maria Ilnicka (z domu Majkowska) — poetka, pisarka, tłumaczka i publicystka. Napisała Ilustrowany skarbczyk Polski (historia Polski w formie rymowanej). Jej ważniejszymi utworami literackimi były: Imieniny dobrej mamy, Księżniczka Beata, Panny Konopianki, Sariusze. (Zob. Literatura polska: przewodnik encyklopedyczny, red. J. Krzyżanowski, t. 1 (A-M), Warszawa 1984, s. 371).
} 
Tańska zalecała sędziwym kobietom udział w życiu rodzinnym, jednak z zachowaniem zdrowego rozsądku i umiaru. Akcentowała znaczenie obecności osób starszych w procesie wychowawczym młodych ludzi. Zdaniem Hoffmanowej, to właśnie osoby starsze powinny stanowić wzór dla nowego pokolenia 4 .

Porady Hoffmanowej adresowane do kobiet odzwierciedlają sposób myślenia jej współczesnych na temat reprezentantek płci słabej. Z treści referowanej tu książki wyłania się powszechnie akceptowany w dziewiętnastym stuleciu wzorzec zachowań kobiecych (zapewne nie do końca odpowiadający rzeczywistości, wyznaczający jednak kierunek, w którym winny zmierzać wszystkie przedstawicielki płci pięknej)5.

Wskazówki zaproponowane przez autorkę podane zostały czytelnikowi w bardzo przystępny sposób. W tekście dominuje proste słownictwo. Styl wypowiedzi jest przejrzysty. W wielu miejscach pobrzmiewa osobisty ton pisarki, a odbiorca dostrzega wyraźną tendencję do zminimalizowania dystansu między nim a autorką.

Zupełnie inny charakter ma publikacja doktora Franciszka Olszewskiego ${ }^{6}$ zatytułowana Starość. Popularny wykład fizjologii, psychologii, medycyny $i$ higieny względnie do wieku starego wydana we Lwowie w 1877 roku. Książka ta jest odpowiedzią na aktualne potrzeby tej części społeczeństwa, która wchodzi w dojrzały wiek. Publikację można uznać za próbę popularyzacji ówczesnego stanu badań. Jest to zarazem jedno z pierwszych obszernych studiów geriatrii.

We wstępie autor jasno określił przeznaczenie pracy i wskazał adresata docelowego, modelowego czytelnika, któremu wiedza podana w książce może okazać się pomocna. Czytelnikiem tym jest każdy starszy człowiek. Tłumaczy to fakt unikania przez autora fachowej terminologii:

Ponieważ książka napisana jest dla publiczności nielekarskiej — stwierdził na wstępie Olszewski — zdało mi się przeto stosownym unikać wyrażeń tak zwanych technicznych, niedawno wyrobionych i dlatego

${ }^{4}$ K. z Tańskich Hoffmanowa, O powinnościach kobiet, [w:] taż, Pisma pośmiertne, t. 5, Berlin 1849, s. $186-191$.

${ }^{5}$ Książka $O$ powinnościach kobiet ukazała się drukiem w 1849 roku. Biorąc pod uwagę datę jej wydania oraz daty graniczne życia autorki, a także ówczesne przekonania dotyczące wieku kobiet powszechnie uznanych za starsze można stwierdzić, że Hoffmanowa pisała swoje dzieło z perspektywy osoby będącej już w wieku dojrzałym. Fakt ten (oraz płeć autorki) wpływały bez zwątpienia na charakter udzielanych przez nią porad.

Z kobiecej perspektywy wskazywała korzyści płynące dla pań z jesieni życia. Podkreślała możliwość ukierunkowania się seniorek w stronę religijności, która przystoi temu wiekowi. Akcentowała brak konieczności rezygnowania z dotychczasowych form samorealizacji. Kobiety mogą bowiem dalej zajmować się domem, w którym zawsze znajdzie się dla nich coś do zrobienia. Powinny śmiało przyznawać się do swojego wieku, który jest ich atutem. Godność, powaga i szacunek do własnej osoby powinny, zdaniem pisarki, charakteryzować każdą z pań. Hoffmanowa zaznaczała jednocześnie, iż zaakceptowanie oznak starzenia się, najtrudniej przychodziło mężczyznom. Panowie przyzwyczajeni do zawodowej aktywności, która wymagała od nich sprawnego umysłu i kondycji fizycznej, nie byli gotowi na nieuchronną zmianę stylu życia. Na ogół nie potrafili, w przeciwieństwie do kobiet, odnaleźć się w przestrzeni domowej.

${ }^{6}$ Zob. S. Kośmiński, Stownik lekarzów polskich, Warszawa 1888, s. 367. 
większej części czytelnikom nieznanych. Życzenia zdrowia niosę wszystkim ludziom szczerze mającym chęci być starymi, żyć na łonie pokoju i szczęścia. Oby ta książka uczyniła zadość ich najważniejszej potrzebie?

Lekarz, próbując określić, czym starość jest, odwołał się do bardzo popularnych wyobrażeń kulturowych ${ }^{8}$ :

Dzielimy życie na cztery: na period wzrostu, dojrzewania, period siły i niemocy. Ostatni ten podział najwięcej upowszechniony stanowi to właśnie, czym są „cztery ludzkie wieki”: wiek dziecięctwa, młodości, męski i starość 9 .

Olszewski, podobnie jak wcześniej Hoffmanowa, nakłaniał osoby starzejące się, a szczególnie kobiety, do pogodzenia się z nieuniknionym. Odradzał paniom stosowanie zabiegów upiększających, które nie dawały, w jego opinii, dobrych rezultatów.

Analizując proces starzenia się człowieka, Olszewski zwrócił uwagę na negatywny wpływ starzenia na psychikę kobiet. Jego zdaniem, nawet najmniejsze zmiany w fizjonomii urastają w ich odczuciu do rangi poważnego problemu. Zmieniający się wygląd fizyczny negatywnie oddziałuje na samoocenę prawie każdej z pań. Próbują one mentalnie, przy pomocy myślenia magicznego, zatrzymać ten proces:

Charakterystyczne objawy starości, wcześniej niż mężczyzn, dotykają kobiety. Ich ukazanie się choćby najmniej wyraźne, jeszcze boleśniej, jeszcze się smutniej na nich odbija. Łudzą się one, jak mogą czas jakiś, pomyłka atoli trwać długo nie może ${ }^{10}$.

W przytoczonym fragmencie Olszewski ukazał starość jako nieustanną tęsknotę za utraconą młodością. Jego zdaniem, smutek towarzyszy najczęściej tym seniorkom, które przez całe życie koncentrowały się jedynie na zachowaniu „atrakcyjnej” powierzchowności. Jej utrata skutkuje pustką wewnętrzną. Istnieje jednak, co podkreślił, również starość dojrzała, pojmowana przez niektórych ludzi jako kolejne, nowe doświadczenie, z którym muszą sobie poradzić. Osoby w ten sposób postrzegające nieuchronny upływ czasu umieją ze spokojem spoglądać wstecz, dokonując rzeczowych podsumowań oraz krytycznej oceny przeszłości ${ }^{11}$.

Zaproponowane przez Olszewskiego metody zaakceptowania wieku podeszłego, polegały na odkryciu jego zalet i jednoczesnym pogodzeniu się z pewnymi uciążli-

\footnotetext{
${ }^{7}$ F. Olszewski, Starość. Popularny wykład fizjologii, psychologii, medycyny i higieny względnie do wieku starego, Lwów 1877, s. 6.

${ }^{8} \mathrm{Na}$ temat kolejnych etapów (faz) życia człowieka jako pewnych wyobrażeń kulturowych zob. A. Gomuła, Starość: kategoria naukowa czy wyobrażenie kulturowe?, [w:] Starość jako wyobrażenie kulturowe, red. A. Gomuła, M. Rygielska, Katowice 2013, s. 12-33. Zob. H. Jakubowska, Spoteczne wytwarzanie starości: definicje, granice, konteksty, [w:] Patrząc na starość, red. H. Jakubowska, A. Raciniewska, Ł. Rogowski, Poznań 2009, s. 15-29.

${ }^{9}$ F. Olszewski, dz. cyt., s. 20.

${ }^{10}$ Tamże, s. 26.

${ }^{11}$ Zob. K. Kozikowska-Koppel, Psychiczne wymiary starości, [w:] Starość, red. A. Nawarecki, A. Dziadek, Katowice 2005, s. 138.
} 
wościami fizycznymi. Wywody Olszewskiego w wielu punktach okazują się zbieżne (zarówno po względem treści, jak i sposobu podania) z tekstem Hoffmanowej. Mimo medycznego przygotowania autora, nie wydają się jednak nowatorskie.

Temat starości był również obecny w publicystyce drugiej połowy XIX stulecia. W tekstach zamieszczanych na łamach czasopism kobiecych redaktorzy nader często podkreślali wartość sędziwego wieku, tym większą, że wraz z upływem lat starsi ludzie stawali się bogatsi o doświadczenia i wiedzę. Publicyści pisali również o towarzyszącym procesowi starzenia pesymizmie.

W jednym z artykułów zamieszczonych w „Bluszczu” Zofia Seidlerowa ${ }^{12}$ dokonała zestawienia pór roku z etapami ludzkiego życia. Ową mało oryginalną refleksję opatrzyła konstatacją, że o ile różnorodność w przyrodzie jest dla potencjalnych obserwatorów atrakcyjna, to przejście w kolejną fazę życia napawa ludzi lękiem oraz tęsknotą za tym, co bezpowrotnie minęło. Poczucie przygnębienia zostaje wzmocnione obserwacją innych, będących w podobnej sytuacji osób, których życie w „poważnym wieku” nie satysfakcjonuje. Odczucia te częściej niż mężczyzn dotyczą kobiet.

Seidlerowa zaproponowała, aby nauczyć się żyć z własną starością i zacząć dostrzegać uroki wieku podeszłego. Taka postawa pomoże odkryć nowe możliwości samorealizacji. Starość okaże się wtedy ciekawym etapem życia, pod wieloma względami lepszym od poprzednich. Należy, co wielokrotnie podkreślała autorka, zaakceptować prawa natury i przyjąć ze spokojem przemijanie:

Starość nie może dzielić wszystkich uciech młodości — z tym pogodzić się trzeba, lecz dla starości otwierają się radości inne: bardziej duchowe, szlachetniejsze i jeśli człowiek stary odczuwa je niezakłamanie, młodzi garną się do niego, a czcią z duszy płynącą otaczają. [...] Wzniesienie się ponad konieczność przejścia, do wieku, który starością zwiemy, pozbawia ją wielu stron przykrych, a rozumnemu zacnemu człowiekowi starość czyni piękną ${ }^{13}$.

Seidlerowa pokazała, jak pogodzić się ze sprawami, których nie można zmienić. W jej opinii, sporo zależy od odpowiedniego nastawienia psychicznego. Wartością podeszłego wieku jest także, co zaakcentowała autorka, umiejętność postrzegania wielu spraw z dystansem emocjonalnym: zrównoważone wnioskowanie oraz możliwość wspierania bliskich „właśnie sercem i zdobytym doświadczeniem”, które „wytwarza uczucie nieopisanej szczęśliwości” ${ }^{14}$.

Oprócz moralizatorskich tekstów, mających ukazać kobietom radości podeszłego wieku, w „Bluszczu” pojawiały się często artykuły krytykujące poddawanie się zabiegom kosmetycznym przez seniorki.

Niektóre zabiegi upiększające wydawały się w owym czasie niedorzeczne i nielicujące z godnością starszych kobiet. Zdecydowanie potępiał je Stanisław Ochocki, a swoją dezaprobatę wyraził w artykule Precz ze starościa ${ }^{15}$. Twierdził on, że starania, aby jak

\footnotetext{
${ }^{12}$ Zofia Seidlerowa (1859-1919) — właścicielka i redaktorka czasopisma kobiecego „Bluszcz”.

${ }^{13}$ Z. Seidlerowa, Piękno w starości, „Bluszcz” 1905, nr 29, s. 327-328.

${ }^{14}$ Tamże, s. 328.

${ }^{15}$ S. Ochocki, Precz ze starością, „Bluszcz” 1905, nr 16, s. 174.
} 
najdłużej cieszyć się młodym wyglądem, kobiety powinny zacząć jak najwcześniej. Później, w podeszłym wieku, powinny zaniechać takich starań, gdyż sędziwe panie, pragnące się odmłodzić, nie tylko narażają się na śmieszność, ale są istotami godnymi pożałowania. Co ciekawe, podobne poglądy w omawianej kwestii miały same kobiety. I tak na przykład Jadwiga Strokowa w artykule Co to jest starość stwierdza, że udawanie, barwienie włosów i „strój wybredny” nie wrócą młodości ${ }^{16}$.

Szczególnie odradzano farbowanie włosów, gdyż, jak powszechnie sądzono, ówczesne sposoby koloryzacji bardzo je osłabiały i niszczyły. Ostatecznie dopuszczano przyciemnianie włosów siwych, ale wyłącznie naturalnymi środkami, za które uznawano korę z orzecha i wierzby, a także jagody mirtu, bzu, liście bluszczu, łupiny orzechów włoskich czy kwiaty maku.

Dla kobiet wchodzących w wiek dojrzały sporym problemem były coraz liczniej pojawiające się zmarszczki. W dziewiętnastowiecznej myśli kosmetologicznej uznawano je za naturalną konsekwencję upływającego czasu, dlatego nie zalecano zwalczania ich za wszelką cenę. Proponowano raczej zabiegi „z domowej apteczki”, pomagające zmniejszyć ich widoczność, a skórze dodać jędrności i elastyczności. Dużą popularnością cieszyły się więc różnego rodzaju maseczki do pielęgnacji skóry twarzy, szyi i dekoltu. Innym sposobem na osiągnięcie pożądanego efektu były okłady z płatków batystowych zwilżonych benzoesem, stosowane miejscowo na te partie skóry twarzy, szczególnie podatnej na powstawanie zmarszczek.

Omawiając zabiegi pielęgnacyjne dla kobiet dojrzałych, warto wspomnieć, że u schyłku XIX wieku ukazywał się dość popularny miesięcznik o nazwie „Poradnik Higieniczno-Kosmetyczny" ${ }^{17}$. Jego wydawcą i redaktorem był magister farmacji oraz chemik sądowy — Jan Ihnatowicz. Struktura miesięcznika była dwudzielna: pierwsza część zawierała rozmaite porady pielęgnacyjne, druga, bardziej rozbudowana (zapewne wskutek aspiracji zawodowych wydawcy), dokładnie omawiała działanie poszczególnych środków higieniczno-kosmetycznych.

Większość przeanalizowanych w tym szkicu publikacji dotyczących problemu starzenia się ma podobny cel. Autorki i autorzy — lekarze, pedagodzy, publicyści starają się przedstawić objawy psychofizyczne towarzyszące wejściu w schyłkową fazę życia. Sporo miejsca w ich tekstach zajmowały wskazówki o charakterze profilaktycznym, mające pomóc czytelnikom w zachowaniu dobrej kondycji.

Nawiasem mówiąc, interesujące spostrzeżenia dotyczące wieku kobiet powszechnie uznawanych za starsze zamieścił Tadeusz Boy-Żeleński we wstępie do tłumaczonego

\footnotetext{
${ }^{16}$ J. Strokowa, Co to jest starość, „Bluszcz” 1903, nr 44, s. 517.

${ }^{17} \mathrm{~J}$. Ihnatowicz, Poradnik Higieniczno-Kosmetyczny, Lwów 1897, nr 1, nr 2, s. 1-10. Jan Ihnatowicz (1848-1918) był autorem książki, której tytuł jest zbieżny z nazwą redagowanego przez niego czasopisma. Zob. Tenże, Poradnik Higieniczno-Kosmetyczny, Lwów 1908. W książce autor zawarł informacje dotyczące między innymi anatomii, higieny i kosmetyki włosów, sposobów pielęgnacji skóry twarzy (jej odmładzania i upiększania), tajników dbania o dłonie i paznokcie, higieny jamy ustnej, przeznaczenia określonych środków kosmetycznych (rozmaitych mydek, wód toaletowych i pachnących, kadzidek, octów). Ihnatowicz opisał działanie środków służących wywabianiu plam różnego pochodzenia oraz wyszczególnił specyfiki do likwidacji insektów i grzyba domowego.
} 
przez siebie dzieła Honorè de Balzaca Kobieta trzydziestoletnia. Zauważył on mianowicie, że tytuł książki w dość prowokacyjny sposób dookreślał wiek kobiety, która według ówczesnych przekonań uchodziła już za bardzo dojrzałą. Stwierdził, iż:

„[...] przed Balzakiem kobieta w ogóle nie ma wieku. Kochanka jest z obowiązku piękna i młoda; nikt jakoś nie zauważył, że w życiu plecie się różnie. [...] Przez parę stuleci abstrakcyjnej literatury nie zauważono, że wiek ludzki odbył tymczasem ewolucję"18.

Balzac, zdaniem tłumacza, podważył konwencjonalne założenia obowiązujące w literaturze, które za podstawę wzięły kult piękna i młodości. Autor Kobiety trzydziestoletniej pokazał życie takie, jakie jawi się ono w rzeczywistości. Ukazał jego cienie, ale również zaakcentował blaski. Trzydziesty rok życia, oznaczający u kobiet wiek dojrzały, to czas pełen uroku i zalet. Dystans wobec metryki, szczególnie w odniesieniu do przedstawicielek płci słabej, oraz sposób postrzegania starości Boy wiązał pośrednio z osobą autora powieści. Tłumacz pisał następująco:

[...] zjawia się pisarz [Balzac], który tę fatalną przed nim i tak głupio poniżoną „trzydziestkę” stroi we wszystkie uroki; który w lekko zmęczonych rysach kobiety widzi całe bogactwo serca i myśli, i zmysłów, o ileż ponętniejsze od banalnych i bezosobistych powabów młodości ${ }^{19}$.

Podsumowując, można pokusić się o wniosek, iż teksty adresowane do seniorów wyczerpująco omawiały proces starzenia się. Publikacje — pisarki Klementyny z Tańskich-Hoffmanowej oraz lekarza Franciszka Olszewskiego stanowią swoiste kompendia geriatrii. Autorzy starali się udzielić odpowiedzi na każde możliwe nurtujące seniorów pytanie. Proponowali konkretne rozwiązania problemów, wychodząc tym samym naprzeciw oczekiwaniom czytelników.

Podawali przykładowy, dokładny plan dnia seniora wraz z precyzyjnym podziałem na poszczególne czynności oraz zaleceniami dotyczącymi zdrowego, racjonalnego odżywiania. Oba teksty zawierały również sugestie dotyczące atrakcyjnych dla starszych kobiet rozrywek. Zalecały aktywne, ale zarazem spokojne zajęcia, unikanie wzruszeń i stresów. Starsi ludzie powinni, wedle autorów, często przebywać na świeżym powietrzu i zażywać ruchu, wzmacniając w ten sposób płuca i przyspieszając obieg krwi.

Uwagi na temat starości, które ukazywały się na łamach „Bluszczu”, nie zawierały nowatorskich spostrzeżeń ani ustaleń. W autorskich sądach nie brakło jednak osobistego zaangażowania. Redaktorzy podkreślali, że starość jest wynikiem długotrwałych i nieodwracalnych procesów fizjologicznych. Wprawdzie trudno określić jej początek, ale w miarę upływu lat objawy starzenia stają się coraz bardziej widoczne i dla niektórych, szczególnie dla kobiet, trudne do zaakceptowania. Dlatego tak ważne były wskazówki pomagające kobietom odkryć w starości prawdziwą wartość i piękno, mające swe źródło w zaletach umysłu.

${ }_{18}^{18}$ T. Boy-Żeleński, Od ttumacza, [w:] H. de Balzac, Komedia ludzka. Kobieta trzydziestoletnia, przekł. T. Boy-Żeleński, Warszawa 1934, s. 6.

${ }^{19}$ Tamże, s. 7. 
Wpływ na uwagi dotyczące starzenia się miały zróżnicowane formy wypowiedzi. W podręczniku geriatrii większy nacisk kładziono na aspekty zdrowotne. Zupełnie inaczej było w publicystyce. Duże znacznie dla ujęcia tematu miały także płeć oraz wiek autorów.

Aldona Jankowska

\section{Find Beauty in the Old Age.}

Woman in the Autumn of Life in the Light of the Selected Texts $19^{\mathrm{TH}}$ and $20^{\mathrm{TH}}$ Centuries

\section{Summary}

The article will present the problems of women's old age in the $19^{\text {th }}$ and $20^{\text {th }}$ centuries. The picture of old age is ambivalent. On one hand old women are associated with wisdom and experience, but on the other hand they are excluded from many fields of life. The old age is a difficult time for women and a kind of cultural taboo. This article is based on the books of Klementyna Hoffmanowa, Franciszek Olszewski and selected journalistic texts in women's magazine "Bluszcz".

Słowa kluczowe: starość, zdrowie, uroda, kobieta, XIX i XX wiek

Keywords: old age, health, beauty, woman, $19^{\text {th }}$ and $20^{\text {th }}$ century 